\title{
Capital Structure and Firm Performance: A comparative Study of Oil \& Gas and Manufacturing Sectors in the United States of America
}

\author{
Adepoju Adeoba Asaolu \\ Correspondence: Adepoju Adeoba Asaolu, FNIMN, ACIB, C/o Department of Banking and Finance, Faculty of \\ Management Sciences, University of Benin, Benin-City, Edo-State, Nigeria.
}

Received: November 23, 2020

doi:10.11114/bms.v7i1.5130
Accepted: January 5, 2021

Online Published: January 16, 2021

URL: https://doi.org/10.11114/bms.v7i1.5130

\begin{abstract}
This paper empirically examines the effects of capital structure on the performances of the Unites States' Oil \& Gas and Manufacturing sectors and investigates the differences in the dynamics of the two sectors. The study employs secondary data sourced from New York Stock Exchange (NYSE)/ NASDAQ for a period of ten (10) years, that is, 2010-2019. It utilized E-View 9.0 for generating the estimation results. The investigation has been performed using panel least square estimation technique and sectoral analysis on the data collected in order to test the set hypotheses. The result shows that although debt structure improved the performances of the firms, a sharp increase in such leverage tends to reduce firm performance for all the firms used. Coefficients namely asset tangibility, interest payment and dividend growth, directors' shares/inside ownership and non-debt tax shield are quite significant in the result. They demonstrate positive relationships, indicating that these variables tend to affect firm performance on the average across both sectors; especially, the results show that the more efficient firms in terms of shielding taxation perform better. The study therefore recommends among other things that selection of debt as a source of capital finance should be done in line with the costs and benefits associated with the use of debt.
\end{abstract}

Keywords: capital structure, liquidity, size, tangibility, Non-Debt Tax Shield (NDTS) and profitability

\section{Introduction}

Capital structure is core to the financing decision of firms because it assists in the assignment of debt and equity into the financing profile. Debts are funds raised via borrowings (largely from banks and the loan market) while equities are those sourced from sale of stocks (securities). Firm reserves the right to choose between the two or embark on the combination of debt and equity or hybrid securities, the overall objective is making the choices out of efficiency in terms of maintaining minimal cost and delivering maximum returns simultaneously.

In firms decisions on leverage, certain factors have to be put into consideration in order not to jeopardize its bottom-line (profit or performance). Aside various theories available, there are also certain variables to be considered for managers to achieve set targets; this paper intends to track the nexus of some of these variables. Internal and macroeconomic factors could be important determinants of various combinations of debt, equity and hybrid securities of firms whereas choices are based on perceived benefits. A good justification for debt is the advantage of tax shelter since interests on loans are tax deductible. Some other firms might choose equity due to the accrued future bonuses and most especially the capital appreciation over time. In terms of risk and cost prevalence, equity appears higher to investors over the risks lenders take for creating debts. While some firms promote either of debt or equity, others opt for optimal mix of debt and equity.

Since the prime objective of firms is the maximization of shareholder's wealth, it is expected that managers perform their financing or the role of building their capital in the best or most efficient way. In overcoming the challenge of choosing its best capital, a firm has to minimize costs and maximize returns to shareholders, according to Pouraghajan and Malekian (2012), it is the capital structure that minimizes a firm's cost of capital, maximizes market value, and increases shareholder's wealth. For existing organizations too, above strategy is applicable in dealing with competition; Ogebe, Ogebe and Alewi, (2013) opine that rightly applied decision is critical not just for the maximization of returns to the various organizational stakeholders, but also because of the impact such a decision will have on the organization's capability in dealing with its competitive environment. Similarly, Morellec, (2001) comments that right decisions should be taken on the firm's debt structure, maturity, decision on mixed debt to certain parties or to the investor, and other types of debt contracts. 
Interests in the study of capital structure could be traced to the earliest work of Modigliani and Miller (1958) concerning their irrelevancy hypothesis assumptions of no transaction costs, free and equal information flow to all stakeholders in the market and free tax to all in a perfect market and their follow up study that relaxed a no-tax assumption and developed a theory about tax benefits of debt, Modigliani and Miller (1963). The main emphasis of their hypotheses is on the nondependence of the value of the firm on the capital structure. The unrealistic assumptions of earlier theory based on the Arrow-Debreu environment ${ }^{1}$ have opened the door to plethora of researches that present the real world situations. This paper therefore attempts to contribute to the subject of capital structure by testing the effects of capital structure on firm performance and sectoral comparison of oil \& gas and manufacturing sectors in the United States. The two sectors were chosen based on their importance to the United States' economy. In terms of significance, this paper would come handy and useful to investors, sectoral regulators, researchers, strategists and the academia.

It is pertinent to state here that the issue of capital structure has been reviewed widely in the United States and other parts of the globe with mixed and/ or inconclusive results/ findings which could be as a result of methodologies used or the timing of reporting. However, more focused methodology and dynamics used in this paper is intended to contribute towards closing some of the earlier gaps or narrow down the conflict of earlier opinions. In line with the objective, this paper therefore answers the question on the effects of capital structure on the performance of oil \& gas and manufacturing companies in the United States considering the following hypotheses: States.

$\mathrm{H}_{0} 1$ : Capital structure has no significant impact on performances of oil \& gas and manufacturing sectors in the United

$\mathrm{H}_{0} 2$ : There is no linear relationship between capital structure and performances of oil \& gas and manufacturing sectors the United States.

$\mathrm{H}_{0} 3$ : There is no difference between oil \& gas and manufacturing sectors in the United States in terms of effects of capital structure on performance.

\subsection{Literature Bases}

The prime of place of capital structure is such that firms need to constantly dissect their portfolios of debt, equity, and hybrid securities to finance assets, operations, and future growth. In reality however, capital structure may be highly complex with numerous sources (conventional and unconventional). Capital structure theories offer fruitful guidance in respect of corporate finance behaviour and practices. It thus goes to say that financing decision could produce substantial impact in achieving corporate goals and objectives. For example, Ramadan and Ramadan (2015) revealed that most profitable firms rely less on borrowing to finance their cash needs and this invariably supports the pecking order theory which confirms an inverse relationship between borrowing and profitability of the firms. Lemma and Negash (2014) found out that a more profitable firm tends to adjust its capital structure more regularly than the less profitable ones. The right combination chosen by the financial manager is crucial to guaranteeing the going concern status of a firm, because employing a wrong mix could seriously hinder the performance and survival of the business (Onaolapo and Kajola, 2010).

\subsection{Conceptual Review}

\subsubsection{Concept of Capital Structure}

Capital structure depicts various windows available to firms to explore in financing their operations; it could take the form of debts, equities or hybrid securities or other non-conventional ways of financing assets. Chandra, Junaedi, Wijaya, Suharti, Mimelientesa and Ng (2015) describe capital structure as the company's permanent financing made up of longterm debt and own capital. Oino and Ukaegbu (2015) define capital structure as the choice between debt and equity financing. Dare \& Sola (2010) define capital structure as the way a corporation can finance its assets through some combination of equity and debt. Capital structure is therefore expedient for decision making in firms, and facilitates maximization of return on investment (ROI). It helps significantly in the efficiency of financing and dividend decisions. Adesina, Nwidobie and Adesina (2015) opine that a firm's capital structure may help as an outcome for deliberate planning by the managers while at other times, it could be the result of combination of situations which the firm had hitherto grappled with.

\subsubsection{Concept of Firm Performance}

The end result or focus of various endeavours and passion is performance. It is dependent on various factors. However, despite its relevance, there is hardly any consensus about its definition, dimensionality and measurement. Several literatures suggest that in terms of organizational performance, researchers find it difficult to define, conceptualise and measure this concept (Taghian, D'Souza and Polonsky, 2015). Lemma and Negash (2014) discovered that more profitable

\footnotetext{
1 Arrow-Debreu environment: A complete markets, no taxes, absence of transaction and bankruptcy costs.
} 
firms tend to adjust their capital structure more regularly than the less profitable ones.

According to Richards, Devinney, Yip and Johnson (2009), performance is the most significant dependent variable for researchers concerned with almost every area of management. Furthermore, (Fan, Titman and Twite 2011) posit that on the issue of corporate performance, there exists some institutional and behavioural differences between firms in emerging markets and those in developed markets. Quite a number of financial and non-financial measures have been adopted in measuring it; these include gross profit, profitability, return on sale (ROS), return on asset (ROA), return on equity (ROE), return on investment (ROI) and revenue growth. Other factors are market share, sales growth (Mokhtar, Yussof and Ahmad, 2014). This study however adopts return on asset (ROA) and return on equity (ROE) as the proxies for performance and comparative studies of oil \& gas and manufacturing sectors in the United States.

\subsubsection{The Concept of Linear Relationship Between Capital Structure and Firm Performance}

It is already 62 years that Modigliani and Miller raised the curtain on capital structure with their irrelevancy approach of the subject to firm value under a set of assumptions. Essentially, they hypothesized perfect markets; it does not matter what capital structure a company uses to finance its operations. They theorized that the market value of a firm is determined by its earning power and by the risk of its underlying assets, and that its value is independent of the way it chooses to finance its investments or distribute dividends. They considered an Arrow-Debreu environment; however, the theory about the debt irrelevance is hardly realistic. There is no gainsaying that capital structure does affect firm's performance; this could either be negative or positive and the level of significance is explored in this paper.

\subsubsection{Firm Size and Capital Structure}

Firm size connotes different thing to different people or segments, while some see size as a measure of a firm's total assets, others relate it to market share value, yet in some quarters, firm size provides a measure of the agency costs of equity and the demand for risk sharing.

Firm size is likely to capture other firm characteristics as well in comparative (peer group) analyses (reputation in debt markets or the extent their assets are diversified). In the study of capital structure, it is relevant to the extent of a firm's total assets.

Amraoui, Jianmu and Bouarara, (2018) conducted a research on 52 Moroccan firms and concluded that among other significant variables only size is significant and positive related to firm performance. Cross-sectional evidence suggests that in most, although not all countries, leverage is positively related to size. (Titman and Wessel, 1998; Rajan and Zingales, 1995; Fama and French, 2002) gave cross-sectional evidence for the Unites States.

\subsubsection{Asset Tangibility and Capital Structure}

A tangible asset is an asset that has a physical form. This includes fixed assets such as buildings, land, plants, office furniture, machineries, among others and current assets such as cash, marketable securities and inventory (these are more easily sellable than fixed assets). While tangible current assets are recorded at the cost incurred to acquire them, the cost for tangible fixed assets may include among others, transportation, installation and insurance costs related to the purchase of fixed assets (Shambor, 2017). Asset tangibility is a very significant determinant of firm's performance/capital structure. Literature has it that there exists a positive relationship between asset tangibility and a firms debt ratio (leverage), that is, the more tangible assets the firms has, the more leverage it has. This is because if firms have more tangible assets which it can easily pledge to secure debt, then the higher the likelihood of increases in debt ratio (Amr and Ayah, 2015). Campello and Giambona (2010), discovered that redeployability of tangible assets is a key determinant of firm capital structure, that is, a key driver of leverage for firms that are more likely to face credit frictions, this is against the existing theory that tangibility is important because creditors could more easily repossess a bankrupt firm's asset, meanwhile often times such assets are illiquid and hard to redeploy. Additional test by the peer shows that assets redeployability facilitates borrowing the most during periods of tight credit in the economy. It is believed from theoretical point of view that tangible assets can be used as collateral in obtaining loans. Therefore higher tangibility lowers the risks of the creditors and increase the value placed on such assets. Most studies show it is positively correlated with leverage.

\subsubsection{Non-Debt Tax Shield and Capital Structure}

Non-debt tax shields (NDTS) are other items apart from interest expenses, which contribute to a decrease in tax payments, such as the tax deduction for depreciation. Depreciation is an effective tax shield; it offsets the tax shield benefit of leverage. According to Modigliani and Miller (1958), interest tax shields create strong incentives for firms to increase leverage. Therefore, where there are non-debt tax shields, they would serve as substitutes for the tax benefit of debt financing. Consequently, there is the tendency for the tax advantage of leverage to decrease when other tax deductions like depreciation increases. Most studies show that NDTS is negatively correlated with leverage. The non-debt-tax shield prediction is principally a departure from the trade-off theory world view of firm leverage. It was advanced by DeAngelo and Masulis (1980) based on the model advanced by Miller (1977) which incorporated personal income tax as a determinant of capital structure. They conjecture 
that tax deductions for depreciation and investment tax credits can be considered as substitutes for the tax benefits of debt financing. These features can lead to market equilibrium, where each firm has an interior optimal leverage (Antoniou, Guney and Paudyal 2008). Thus it seems that firm leverage is also determined by intangible assets such as depreciation which substitute the benefits derived from debt-interest tax shield. The a priori expectation from a trade-off theory premise therefore is that, firm-leverage is inversely associated with non-debt tax shield.

\subsubsection{Dividend Growth and Capital Structure}

Dividend growth is an immensely important statistic for investors to focus on because investors are habitually attracted to stocks that have high dividend yields. However, what is more important than the current size of the dividend is the pace at which it has been growing (or shrinking); this invariably informs decisions taken by shareholders/ investors. Dividend growth rate is the annualized percentage rate of growth that a particular stock's dividend undergoes over a period of time. The time period included in the analysis could be of any interval desired and usually calculated by using the least squares method or by simply taking a simple annualized figure over the time period (Investopedia, 2018). Frank and Goyal (2009) contend that, growth increases costs of financial distress, reduces free cash flow problems, and exacerbates debt-related agency problems. Growing firms place a greater value on stakeholder co-investment. Thus, the trade-off theory predicts that growth reduces leverage. Antoniou et al (2008) posit that a negative relation is expected between growth opportunities and leverage for two main reasons.

Lemma and Negash (2014) also find an inverse relationship between firm leverage and dividend payout ratio. Their work was based on a study of firms drawn from nine developing economies in Africa being; Botswana, Egypt, Ghana, Kenya, Mauritius, Morocco, Nigeria, South Africa, and Tunisia.

\subsubsection{Directors Shares/Inside Ownership and Capital Structure}

Obviously, it is a contemporary way of introducing the concept of corporate governance into the mode of capital structure. Mursalim and Kusuma (2017) made findings on corporate governance and capital structure. The study confirms positive correlation of corporate structures with leverage, he was however, not specific on any variable. Similarly, Demsetz and Villalonga (2001) drew a positive conclusion on the positive relationship between ownership structure and corporate performance. The author therefore attempts to measure this important aspect of corporate governance/ behavioural finance on capital structure in terms of Director's shares/ inside ownership. There is no doubt that the internal structuring/ ownership of an organization could be an important determinant of choice of capital structure. It would help ventilate the views of owners regarding which structure of capital to be selected in financing their operations. Including this variable would answer questions on what structure of capital owners prefer? Furthermore, factoring this variable would offer how corporate governance measure affects leverage, more so in important sectors like the oil \& gas and manufacturing sectors.

\subsubsection{Interest Payment and Capital Structure}

Interest rates primarily influence a firm's capital structure by affecting the cost of debt capital. Debt capital refers to money that is borrowed from a lender. Common types of debts are bank loans, personal loans, credit card debt and bonds.

An interest expense is the cost incurred by an entity for borrowed funds. It represents interest payable on any borrowings. It is derived as the natural logarithm of the interests on loan (Kakilli-Acaravci, 2015). 


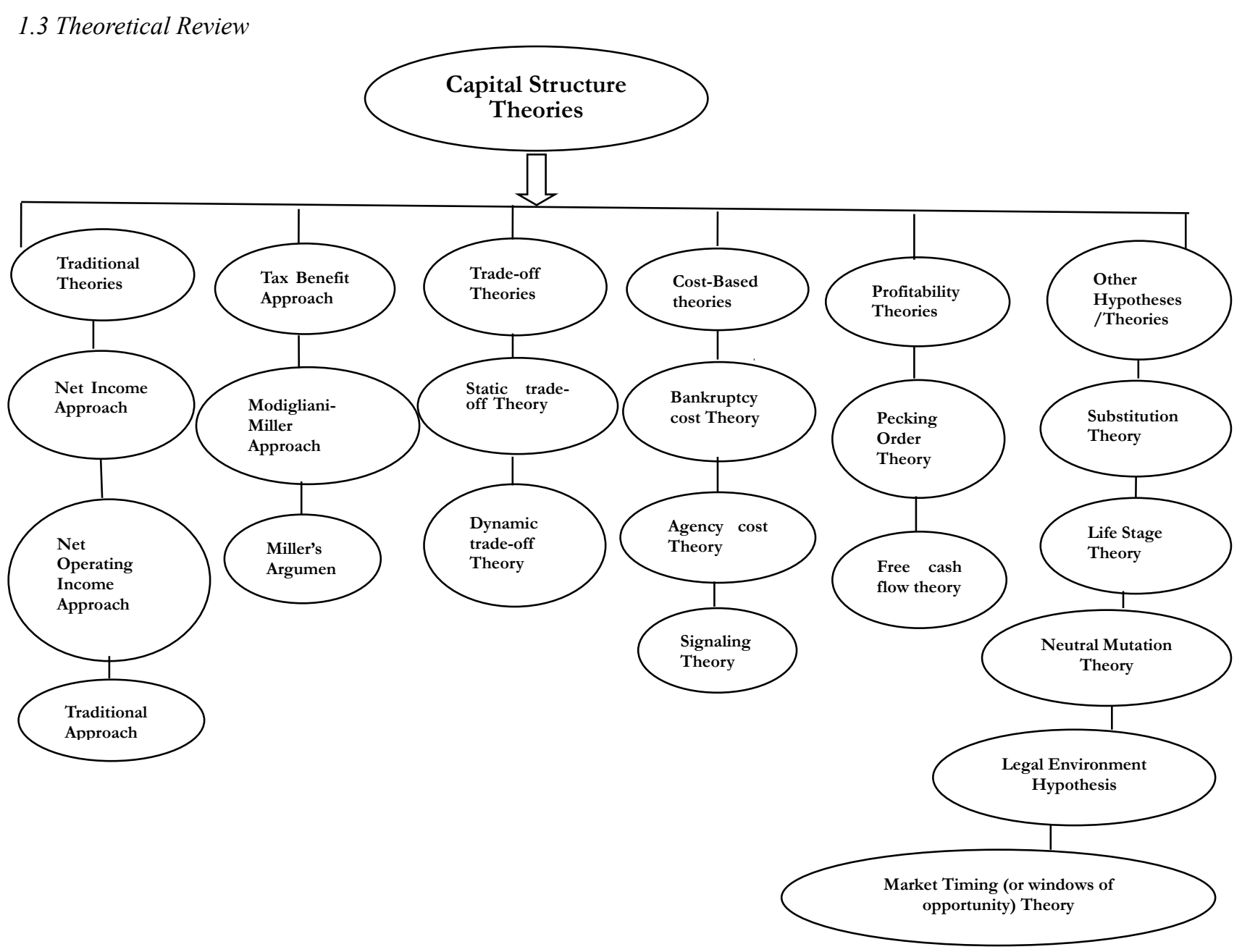

Figure 1. Schematic presentation of capital structure theories

Author's design/ Additions 2020) (Original version: Tewara, 2016)

\subsection{Empirical Literature}

Many studies have conducted empirical tests to explain how firms chose between debt and equity and their relative proportion in firm financing (Dittmar and Thakor, 2007).

Endri and Fathony (2020) on the determinants of firm's value in the financial industry find that growth has a positive effect on financial performance.

Endri, Ridho, and Harahap (2019) on relationships between firm performance and capital structure in Indonesia using three performance metrics (ROE, ROA and EPS) as dependent variables and five leverage measure which are debt to asset ratio (DAR), debt to equity ratio (DER), long term debt to total capital (LDTC), long term debt to total equity (LDTE), and growth as independent variable conclude that during period 2014-2018, the most profitable mining sector companies were those who maintained a high proportion of debt in their capital mix, avoiding shareholder equity.

Amraoui, Jianmu and Bouarara (2018), discovered that on the determinants of capital structure and financing choice of Morroccan firms between 2009 -2016, only size has positively significant impact on capital structure, while asset tangibility, and liquidity, among others have significantly negative impact on firm's performance, growth was found not to be related. They concluded that the main determinants of capital structure in Morrocco are firm's specific factors and the choice of leverage varies from industry to industry according to the specifics of its activities.

Dokua, Adjeib, Adjimahc and Akumad (2017) deployed OLS regression analysis on two listed oil marketing companies in Ghana between 2005 and 2014 discovered that profitability, asset tangibility, growth, size and riskiness of a firm impact positively on the capital structure.

Akeem, Terer, Kiyanjui and Kayode (2014) on the impact of capital structure on manufacturing firms' performance in Nigeria using descriptive statistics and regression analysis on manufacturing firms' performance in Nigeria between 2003 
and 2012 finds that capital structure is negatively related to firm's performance

Emeh and Okoli (2015) utilized regression analysis on the determinants of capital structure in Nigeria's listed oil \& gas companies during 1990 - 2012; their findings revealed that profitability, tangibility, non-tax debt shield, size, growth opportunities and earnings volatilities are all determinants of capital structure in oil and gas sector of Nigerian economy consistent with the determinants of capital structure in developed and other developing countries. The financing decision of oil and gas sector of Nigerian economy is more skewed towards the pecking order theory of capital structure more than the trade-off theory.

Kakilli-Acaravci (2015) deployed panel data regression methods on 79 listed firms in Turkey (1993-2010) on the determinants of capital structure in the Turkish manufacturing sector. Their findings show that leverage has significant relationships with growth opportunities, size, profitability, tangibility and growth. But non-debt tax shields explanatory variable has insignificant effect on leverage. The result on growth supports the trade-off theory. Whereas, size, profitability and assets tangibility support the pecking order theory. On the other hand, profitability and growth opportunity variables have more significant effects than other variables.

Ramadan and Ramadan (2015) using Ordinary Least Square (OLS) regression model on 72 industrial Jordanian Companies listed on Amman Stock Exchange (2005-2013) on capital structure and firm's performance of Jordanian manufacturing sector discover statistically significant inverse relationship between capital structure and the performance of the Jordanian industrial companies expressed by return on asset ratio (ROA), which means that the most profitable companies rely less on borrowing to finance their cash needs. This is in tandem with pecking-order theory.

Hassan and Samour (2015) conducted a cross-industry study with two-panel regression analyses on capital structure in the United States firms within consumer goods, consumer services, healthcare, industrials and technology before and during the financial crisis. They discovered that the capital structure changed differently among the industries and a significant effect of the crisis in the consumer services and healthcare industry was discovered. Also, the results indicate that the impact of capital structure on firm performance is industry-specific.

Frank and Goyal (2009) used descriptive analyses and median approach to analyse publicly traded firms in the United States (1950 -2003) on the reliably important factors in capital structure decisions. The result shows that the most reliable factors for explaining market leverage are: median industry leverage (it has positive effect on leverage), market-to-book assets ratio (has negative effect on leverage), tangibility (Positive effect), profits (negative effect), log of assets (positive effect), and expected inflation (positively related to leverage). Additionally, they discovered that dividend-paying firms tend to have lower leverage. They also found a significant positive relationship between the size of the firm and leverage

Bevan and Dabolt (2004) using correlation / regression analyses done across some sectors in testing for inconsistencies in the estimation of UK capital structure determinants reveal a significant positive relationship between the size of the firm and leverage.

Rajan \& Zingales (1995) conducted a cross-sectoral analysis on the determinants of capital structure in the G-7 countries. This was done by analyzing the financing decisions of public firms in the major industrialized countries. They discovered that an aggregate level, firm leverage is fairly similar across the G-7 countries. The study finds that factors identified by previous studies as correlated in the cross-section with firm leverage in the United States are similarly correlated in other countries as well. However, a deeper examination of the U.S. and foreign evidence suggests that the theoretical underpinnings of the observed correlations are still largely unresolved.

\section{Methodology}

The study employed the use of secondary data. The data on the oil \& gas and manufacturing firms in the United States were sourced from New York Stock Exchange (NYSE/ NASDAQ). A panel data set was used in the empirical analysis of the data over a period of ten (10) years, that is, 2010-2019.

\subsection{Model Specification}

The major thrust of this study is to examine the effects of firm performance in Oil \& Gas and manufacturing sectors in the Unites States and by extension measure the extent to which these factors contribute to the firms' performances. It also conducted a sectoral analysis on the two sectors. In line with the paper's framework, the baseline regression model specified is non-linear formats were not only the level of capital structure, but its sharp increases have impact on firm's performance. The framework shows the debt is beneficial to the firm up to a certain level and thereafter continuous application of debt beyond the required threshold continue to yield negative returns on the overall performance of the firm; the quadratic function adequately captures this effect.

\subsubsection{Model I. Effects of Capital Structure on Firm Performance}

The baseline model specifies that the performance indicator is explained by the capital structure in terms of a certain 
coefficient of interaction. Thus, in functional form, the model is specified as follows:

$$
\mathrm{y}=\mathrm{f}(\mathrm{lev}) ; \mathrm{f}_{\mathrm{lev}}>0
$$

That is, firm performance ' $y$ ' is a function of firm capital structure (leverage), and fulfills the non-negativity assumption. Given that other related factors explain firm performance, the baseline model could be expanded to be shown as:

$$
\mathrm{y}=\mathrm{a}+\mathrm{b}_{1} \text { lev }+\mathrm{X}_{\mathrm{i}} \beta+\epsilon_{\mathrm{i}}
$$

where $X=$ a vector of other explanatory variables and $\epsilon$ is the stochastic error term that is assumed to be identical and independently distributed (iid).

The model can thus be expanded and presented as an adaptation of Chou and Lee (2010) model in a quadratic form (where firm's performance was related only to leverage and its squared value in the form):

$$
y=a+b_{1} l e v+b_{2} l e v^{2}+u
$$

Where $y=$ the firm value, lev is leverage and $u$ is the error term. The quadratic model is hereby specified as:

$$
\mathrm{y}_{\mathrm{i}}=\alpha_{0}+\alpha_{1} \operatorname{lev}_{\mathrm{i}}+\alpha_{2} \operatorname{lev}_{\mathrm{i}}^{2}+\mathrm{X}_{\mathrm{i}} \beta+\epsilon_{\mathrm{i}}
$$

(all the variable are as earlier explained)

\subsubsection{Model II. Sectorial Comparison}

A dummy variable is used in the comparison between oil \& gas and manufacturing sector to capture the industry effect of firm performance within the model. Therefore the equation is re-estimated for a pool of all the firms (for both oil and gas and manufacturing sectors) with a dummy included to indicate the sector. The re-estimated equation in panel least square format is presented:

$$
y_{i}=\alpha_{0}+\alpha_{l} l e v_{i t}+\alpha_{2} \operatorname{lev}_{i t}^{2}+X_{i t} \beta+\epsilon_{i t}+ø d u m m y+u
$$

Where; $\mathrm{y}=$ proxy for performance (ROA and ROE); lev =leverage (for oil \& gas and manufacturing industries); $\mathrm{t}=$ value of a firm in period $t ; \epsilon=$ error term; $\mathrm{u}=$ control variable, $\mathrm{X}_{\mathrm{i}}=$ vector of other determinants (that is; firm size, asset tangibility, non-tax debt shield (ndts)), dividend growth, director's shares/inside ownership and interest payment, $\mathrm{i}=$ each firm in the industry and $\beta=$ the parameter used.

where Dummy $=$; and all the variables are as earlier defined.

a priori expectation is thus; $\alpha_{1}>0, \alpha_{2}>0 ; X_{i}>0$.

\subsubsection{Description of Terms/ Operationalization of Variables}

A number of firm-level characteristics have been identified in previous empirical studies that examined capital structure and these include; firm size, asset tangibility, non-debt tax shield, growth opportunities, tax, non-debt tax shield, industry classification, among others:

a. Total assets $=$ current + noncurrent assets (must equal total liabilities + stockholders' equity combined).

b. Equity $=$ Assets - Liabilities

c. Return On Assets $(R O A)=$ Profit After Tax $(\mathrm{PAT})$ Total Assets.

d. Return On Equity $(R O E)=$ Profit After Tax (PAT) Equity

e. Leverage $(l e v)=$ Debt Equity

f. Firm Size $($ size $)=$ Natural logarithm of total assets

g. Asset Tangibility $($ tang $)=$ Fixed assets total assets

h. Non-Debt Tax Shield $(n d t s)=$ Annual Depreciation total assets

i. Dividend Growth $(\operatorname{divg})=$ current dividend and previous previous dividend ( that is, $\mathrm{y}_{2}-\mathrm{y}_{11} \mathrm{y}_{1} * 100$ )

j. Director's Shares/Inside ownership (dir_in) = Director's shares outstanding shares of the firm.

k. Interest payment $($ int $)=$ Natural logarithm of interest paid.

\section{Results \& Analyses (Data Presentation and Analyses)}

\subsection{Descriptive Statistics}

Descriptive statistics show the summary of data and other basic characteristics within the series. The annualized summary statistics for the main variables in the study are presented for the sampled industrial sectors for each of the countries since this will provide more nuanced background information for the bahaviour of each variable in the sectors. 
Table 1. Descriptive Statistics

\begin{tabular}{|c|c|c|c|c|c|c|c|c|c|}
\hline Variable & roa & Roe & Lev & tang & Ndts & $\operatorname{divg}$ & dir_in & Intr & size \\
\hline \multicolumn{10}{|c|}{ United States manufacturing } \\
\hline Mean & 2.69 & 0.25 & 0.41 & 14.27 & 2.54 & 0.16 & 7.07 & 6490.00 & 11.67 \\
\hline Std. Dev. & 9.34 & 0.31 & 0.54 & 51.37 & 9.13 & 1.87 & 13.25 & 12376.73 & 1.65 \\
\hline$J-B$ & 485.28 & 10164.93 & 162.91 & 466.88 & 475.82 & 5163.22 & 173.41 & 133.51 & 48.48 \\
\hline Prob. & 0.00 & 0.00 & 0.00 & 0.00 & 0.00 & 0.00 & 0.00 & 0.00 & 0.00 \\
\hline \multicolumn{10}{|c|}{ United States oil and gas } \\
\hline Mean & 0.11 & 0.30 & 0.10 & 0.58 & 0.04 & -0.12 & 0.27 & 104877.00 & 15.85 \\
\hline Std. Dev. & 0.07 & 0.26 & 0.09 & 0.38 & 0.02 & 0.40 & 0.32 & 209287.80 & 2.22 \\
\hline$J-B$ & 2.34 & 8.02 & 14.51 & 2.41 & 1.08 & 28.30 & 30.59 & 152.91 & 1.58 \\
\hline Prob. & 0.31 & 0.02 & 0.00 & 0.30 & 0.58 & 0.00 & 0.00 & 0.00 & 0.45 \\
\hline
\end{tabular}

Source: Author's computation (using EView 9.0), 2020.

From table 1, mean ROA is 2.69 for the manufacturing sector, while average ROA in the oil and gas sector is 0.11 . Apparently, performance viewed from the perspective of asset substantiation is a bit high for the Unites States' firms. The standard deviations for the ROA variables at all levels are relatively low, and indicate that the average performance indicator for each sector is relatively even across the firms. Return on equity (ROE) did not perform as high as ROA for all the sector groups. Average ROE is 0.25 and 0.3. These return indicators suggest that asset management activities are rather more impressive than shareholder-focused management activities in the firms. Indeed, operational efficiency supersedes excessive expansion of shareholders' wealth among the firms. For ROE also, standard deviation values are moderate and suggest even distribution of the values along the mean position. There does not appear to be certain firms within the sectoral groups that exhibit extreme performance indicators among the sampled groups. This is both interesting in terms of management and performance patterns within sectors and in terms of statistical and econometric analyses of the study.

In terms of the capital structure (as measured by leverage), the average values are 0.41 and 0.10 for manufacturing and oil and gas sectors respectively suggesting that this variable does not follow a given pattern between industries. It thus appears that firms in the manufacturing industry have a higher mix of debt in their capital, this could be as a result of the nature of business activities per industry. The standard deviation for the leverage series in each group is also moderate in relation to the respective mean values, also implying smoothness in leverage patterns among firms in each sector, without large outliers. The other summary statistics for the variables indicates that the distribution of the variable among the firms is not symmetric, for example, asset tangibility and non-debt-tax shield are much higher for manufacturing firms, in the same vein, the size of firms in the United States are large firms, whereas its dividend growth is quite low. A special statistic of interest in this study is the Jarque Berra coefficients in the summary statistics. It shows the degree of normality, and hence the heterogeneity of the data series. Highly heterogenous series are the precursors for panel data estimation techniques. The J-B statistics for almost all the variables are very large and highly significant at the 1 percent level and implies that the probability distribution of the sample for the variable is not normally distributed. This invariably suggests that the series across the firms is heterogeneous and exhibit firm-specific characteristic. This is one justification for the application of the panel data estimation technique in this study. 
Table 2. Correlation Matrix

\begin{tabular}{|c|c|c|c|c|c|c|c|c|}
\hline & ROA & ROE & LEV & TANG & NDTS & DIVG & DIR_IN & INTR \\
\hline \multirow{2}{*}{ ROE } & -0.02 & & & & & & & \\
\hline & 0.71 & & & & & & & \\
\hline \multirow[t]{2}{*}{ LEV } & -0.09 & -0.02 & & & & & & \\
\hline & 0.13 & 0.66 & & & & & & \\
\hline \multirow[t]{2}{*}{ TANG } & 1.00 & -0.05 & -0.08 & & & & & \\
\hline & 0.00 & 0.38 & 0.16 & & & & & \\
\hline \multirow[t]{2}{*}{ NDTS } & 1.00 & -0.05 & -0.08 & 1.00 & & & & \\
\hline & 0.00 & 0.40 & 0.16 & 0.00 & & & & \\
\hline \multirow[t]{2}{*}{ DIVG } & -0.02 & 0.07 & -0.03 & -0.02 & -0.02 & & & \\
\hline & 0.71 & 0.25 & 0.61 & 0.68 & 0.68 & & & \\
\hline \multirow[t]{2}{*}{ DIR_IN } & 0.74 & -0.05 & 0.06 & 0.75 & 0.75 & 0.02 & & \\
\hline & 0.00 & 0.39 & 0.28 & 0.00 & 0.00 & 0.69 & & \\
\hline \multirow[t]{2}{*}{ INTR } & -0.03 & -0.01 & 0.01 & -0.03 & -0.03 & 0.08 & -0.07 & \\
\hline & 0.56 & 0.92 & 0.90 & 0.56 & 0.55 & 0.16 & 0.21 & \\
\hline \multirow[t]{2}{*}{ SIZE } & -0.01 & 0.03 & 0.12 & -0.01 & 0.00 & 0.07 & 0.18 & 0.30 \\
\hline & 0.88 & 0.65 & 0.04 & 0.92 & 0.93 & 0.20 & 0.00 & 0.00 \\
\hline
\end{tabular}

Source: Author's computation (using EView 9.0), 2020.

To further examine the characteristics of the data for the sampled firms, the correlation matrix among the variables is reported in table 2 . The correlation analysis helps us identify the initial relationships among the variables and also helps confirm that the explanatory variables are not excessively correlated. Surprisingly, a negative correlation is reported between ROA and ROE, though the coefficient is not significant at the 5 percent level. However, given that both svariables measure performance for the firms, the negative correlation suggests a trade-off between efficiency performance among the firms. Apparently, as one of the indicators is rising, the other falls. It could also reveal an underlying characteristic among the firms, namely, that one return is often sacrificed in pursuit of the other. This is an interesting outcome for this correlation analysis. Also, there are many insignificant relationships among the explanatory variables in the study, given the weak t-values for the correlation coefficients. This indicates that factors that explain performance in the firms (especially factors relating to capital or debt structure) do not generally move together in the firms. For the relationships, a very strong positive relationship exists between $n d t s$ and asset tangibility with a correlation coefficient of 1 . The ratio of directors' shares has significant positive relationship with both tang and $n d t s$. While size is positively correlated with leverage, ratio of directors' shares, and interest payments. This implies that larger firms tend to have higher leverage and more directors' share participation.

\subsection{Panel Unit Test Result}

Since non-stationary panel data pose some challenges in regression analysis, it is thus important to check the time series properties of panel data before analysing the relationship that exist among the variables. It has been well established in the literature that regression result produces spurious estimate while using data that is not stationary (have unit root). To avoid a spurious regression result, panel unit root test was performed on all the variables used in this study. Levin, Lin and Chu (2002) (LLC) unit root test as well as Im, Persaran and Shin (2003) (IPS) specification are used to test for the presence of a unit root in the panel data. Since the characteristics of the firms involved in the study are likely to be heterogeneous in nature, IPS test was preferred to LLC unit root test. However, LLC unit root test results were used to confirm IPS test results. Individual intercept was included in the equation in all the mentioned unit root tests. The lag length for each variable was automatically selected by Schwartz Information Criterion ${ }^{2}$ (SIC) and individual intercept

\footnotetext{
${ }^{2}$ Schwarz criterion (also SBC, SBIC) or Bayesian information criterion (BIC) is a criterion for model selection among a finite set of models; the model with the lowest BIC is preferred. It is based, in part, on the likelihood function and it is closely related to the Akaike information criterion (AIC). When fitting models, it is possible to increase the likelihood by adding parameters, but doing so may result in overfitting. Both BIC and AIC attempt to resolve this problem by introducing a penalty term for the number of parameters in the model; the penalty term is larger in BIC than in AIC. The BIC was developed by Gideon E. Schwarz and published in a 1978 paper; 'Estimating the dimension of a model' (Wikipedia, 2017).
} 
was included in the test equation for all the variables. Newey-West Method ${ }^{3}$ was equally applied to choose the optimal lag length or bandwidth.

Table 3. Panel Unit Root Tests with Individual Intercept

\begin{tabular}{|c|c|c|c|c|c|c|}
\hline \multirow[t]{2}{*}{ Variable } & \multicolumn{3}{|l|}{ LLC } & \multicolumn{3}{|l|}{ IPS } \\
\hline & Level & First Diff & Status & Level & First Diff & Status \\
\hline \multirow[t]{2}{*}{ ROA } & -7.7251 & ------ & $\mathrm{I}(0)$ & -9.0663 & ------ & $\mathrm{I}(0)$ \\
\hline & {$[0.0000]^{*}$} & ------ & & {$[0.0000]^{*}$} & ------ & \\
\hline \multirow[t]{2}{*}{ ROE } & -5.1026 & ------ & $\mathrm{I}(0)$ & -6.7829 & ------ & $\mathrm{I}(0)$ \\
\hline & {$[0.0000]^{*}$} & ------ & & {$[0.0000]^{*}$} & ------ & \\
\hline \multirow[t]{2}{*}{ LEV } & -10.5367 & ------ & $\mathrm{I}(0)$ & -5.2042 & ---- & $\mathrm{I}(0)$ \\
\hline & {$[0.0000]^{*}$} & ------ & & {$[0.0000]^{*}$} & ---- & \\
\hline \multirow[t]{2}{*}{ TANG } & -13.2998 & ---- & $\mathrm{I}(0)$ & -7.3098 & ---- & $\mathrm{I}(0)$ \\
\hline & {$[0.0000]^{*}$} & ----- & & {$[0.0000]^{*}$} & ----- & \\
\hline \multirow[t]{2}{*}{ NDTS } & -2.6321 & ----- & $\mathrm{I}(0)$ & -6.8233 & ----- & $\mathrm{I}(0)$ \\
\hline & {$[0.0042]^{*}$} & ----- & & {$[0.0000]^{*}$} & ----- & \\
\hline \multirow[t]{2}{*}{ DIVG } & -14.1678 & ------ & $\mathrm{I}(0)$ & -6.9787 & ---- & $\mathrm{I}(0)$ \\
\hline & {$[0.0000]^{*}$} & ------ & & {$[0.0000]^{*}$} & ----- & \\
\hline \multirow[t]{2}{*}{ DIR_IN } & -3.8175 & ---- & $\mathrm{I}(0)$ & -6.6775 & ----- & $\mathrm{I}(0)$ \\
\hline & {$[0.0001]^{*}$} & ---- & & {$[0.0000]^{*}$} & ----- & \\
\hline \multirow[t]{2}{*}{ INTR } & -15.6155 & ----- & $\mathrm{I}(0)$ & -6.4632 & ----- & $\mathrm{I}(0)$ \\
\hline & {$[0.0000]^{*}$} & ----- & & {$[0.0000]^{*}$} & ----- & \\
\hline \multirow[t]{2}{*}{ SIZE } & -15.7572 & ------ & $\mathrm{I}(0)$ & -7.6773 & ----- & $\mathrm{I}(0)$ \\
\hline & {$[0.5347]^{*}$} & ----- & & {$[0.0000]^{*}$} & ----- & \\
\hline
\end{tabular}

Note: The values in the square bracket [ ] are the probability values; $(*)$ indicates significant at $1 \%$.

Source: Author's Computation (using EView 9.0), 2020.

From Table 3, it is observed that all the variables are stationary at level $\mathrm{I}(0)$ at $5 \%$ significance level.

${ }^{3}$ Newey-West estimator is used in statistics and econometrics to provide an estimate of the covariance matrix of the parameters of a regression-type model when this model is applied in situations where the standard assumptions of regression analysis do not apply. It was devised by Whitney K. Newey and Kenneth D. West in 1987, although there are a number of later variants. The estimator is used to try to overcome autocorrelation (also called serial correlation), and heteroskedasticity in the error terms in the models, often for regressions applied to time series data. (Wikipedia, 2017). 
Table 4. Baseline Results for Combined Data (ROA)

\begin{tabular}{|c|c|c|c|c|}
\hline \multirow[b]{2}{*}{ Variable } & \multicolumn{2}{|l|}{ OLS } & \multicolumn{2}{|l|}{ GLM } \\
\hline & Coefficient & Prob. & Coefficient & Prob \\
\hline Constant & 0.170 & 0.11 & -1.675 & 0.00 \\
\hline roa $(-1)$ & 0.077 & 0.00 & 0.006 & 0.00 \\
\hline Lev & -0.137 & 0.11 & 1.249 & 0.07 \\
\hline$l e v^{\wedge} 2$ & 0.039 & 0.20 & -3.461 & 0.00 \\
\hline Tang & 0.060 & 0.00 & 0.009 & 0.00 \\
\hline Int & 0.140 & 0.13 & 5.298 & 0.00 \\
\hline Divg & 0.022 & 0.46 & 0.313 & 0.00 \\
\hline dir_in & -0.006 & 0.12 & 0.010 & 0.00 \\
\hline$N d t s$ & 0.621 & 0.00 & 0.022 & 0.00 \\
\hline Size & -0.024 & 0.07 & -0.678 & 0.00 \\
\hline$U S$ & -0.043 & 0.48 & -3.213 & 0.00 \\
\hline Man & 0.141 & 0.01 & 3.708 & 0.00 \\
\hline$R$-squared & 0.995 & & -- & -- \\
\hline Adjusted R-squared & 0.995 & & -- & -- \\
\hline F-statistic & 5841.1 & & -- & -- \\
\hline LR statistic & & & $293014.3[\mathrm{p}$ & \\
\hline
\end{tabular}

Source: Author's computation (using EView 9.0), 2018.

The earlier estimation procedures involve the baseline equations (which where estimated for individual sectors) and estimation of overall equation with sectoral dummies. These estimations are hereby demonstrated which involves estimation of the overall model of all sectors and firms, with dummies identifying sectoral effects.

\subsection{The Overall Model on Determinants of Firm Performance}

The result of the model using all the data in the sample is presented in table 4. It should be noted that firm performance is presented in terms of return on asset and return on capital. For the result on ROA, the outcome is shown using both the OLS estimates and the Generalised Least Squares (GLS) techniques. The results of the GLM estimates exhibit more robust outcomes in terms of individual significance of explanatory variables. From the result, coefficient of lagged ROA is positive and significant in both results, although the coefficient is very low, suggesting a very slow adjustment to long run equilibrium for the firms. In particular, we focus on the GLM estimates. Furthermore, the coefficient of leverage in level has a probability value of 7 percent (and therefore not significant) indicating that larger leverage or high debt combination in the firms tends to lead to decrease in ROA in the firms. The coefficient however fails the significance test at 5\% level. This indicates that leverage is stimulating factor in firm performance based on the sampled firms in the study. The coefficient of squared leverage is also significant but negative. Thus, this result suggests that though debt structure leads to improved performance of the firms, whereas, sharp increases in such leverage tends to reduce firm performance for all the firms. Only size is insignificant in the result while asset tangibility, interest payment and dividend growth are all positive in the result, indicating that increases in these variables tend to improve firm performance on the average. The coefficient of ratio of Director's shares and that of non-debt tax shield are also positive. It all reveals that firms that are shielded from taxes perform better. The coefficient of firm size is also significant at the 1 percent level, though it is negative which shows that firm size has a significant negative impact on performance. A major variable of interest in this section is the coefficient of sectoral distribution. In order to avoid the problem of dummy variable trap, only the dummy for manufacturing sector is included in the result. Thus, the outcome of the sectoral share is interpreted as related to that of the oil and gas sector, making the coefficient of the constant term to be interpreted as that of oil and gas dummy. From the table, it is seen that the coefficient of both manufacturing sector dummy and that of oil and gas are significant at the one percent level and positive. On the other hand, while that of oil and gas is negative that of manufacturing is positive. This shows that manufacturing firms tend to exhibit a higher propensity to perform better (in terms of ROA) at any given capital structure than the oil and gas sector firms. Moreover, performance of manufacturing sector firms also tend to decline faster at sharp and very high rates of leverage in comparison to oil and gas firms. From the result, it is shown that 
the effects of the two sectors on performance at any given level of leverage is significantly different with that of manufacturing sector exerting stronger influences.

Table 5. Baseline Results for Combined Data (ROE)

\begin{tabular}{l|ll|ll}
\hline & OLS & & GLM & \\
\hline Variable & Coefficient & Prob. & Coefficient & Prob. \\
\hline Constant & 0.224 & 0.20 & 0.136 & 0.2 \\
roe(-1) & 0.207 & 0.00 & 0.174 & 0.00 \\
Lev & -0.164 & 0.24 & -0.675 & 0.14 \\
lev^2 & 0.052 & 0.29 & 0.052 & 0.28 \\
Tang & -0.016 & 0.41 & -0.019 & 0.40 \\
Int & 0.326 & 0.03 & 0.297 & 0.03 \\
Divg & 0.056 & 0.25 & 0.070 & 0.35 \\
dir_in & -0.001 & 0.88 & -0.021 & 0.81 \\
Ndts & 0.083 & 0.46 & 0.098 & 0.47 \\
Size & -0.032 & 0.14 & -0.030 & 0.14 \\
US & -0.165 & 0.10 & -0.203 & 0.01 \\
Man & 0.246 & 0.00 & & \\
\hline R-squared & 0.096 & & & \\
Adjusted R-squared & 0.062 & & & \\
F-statistic & 2.87 & & 31.60643 [prob. $=0]$ \\
LR statistic & & & \\
\hline Soures A & & &
\end{tabular}

Source: Author's computation (using EView 9.0), 2020

The result for return on equity is presented in table 5 with the dummies on sector. The results for the ROE are poorer than that of ROA, suggesting that leverage and the other factors track ROA better than ROE. The coefficients of leverage and its squares both fail the significance test at the 5 percent level, while that of tangibility and firm size also fail the significance test. Importantly, the coefficient of manufacturing dummy is significant at the 1 percent level and also positive, while that of the constant term (oil and gas) fails the test, though it is positive. Thus, like the ROA result on manufacturing, there is a significant difference between the influences capital structure have on firm performance for firms in the manufacturing sector and those in oil and gas sector.

\subsection{Sector-Based Results}

Here both the baseline (linear) and non-linear estimations are presented for the sectors. This helps to identify different effects of leverage and lower and higher levels, on firm performance.

Table 6. The Linear Estimates using ROA

\begin{tabular}{l|ll|ll}
\hline \multirow{2}{*}{ Variable } & \multicolumn{2}{l}{ United States } & \multicolumn{2}{l}{ Oil and gas } \\
\cline { 2 - 5 } & \multicolumn{2}{l}{ Manufacturing } & Coefficient & Prob. \\
\cline { 2 - 5 } roa(-1) & Coefficient & Prob. & 0.033 & 0.31 \\
Lev & 0.614 & 0.00 & 0.642 & 0.02 \\
Tang & 0.361 & 0.00 & -0.042 & 0.21 \\
Ndts & 0.120 & 0.01 & 0.900 & 0.00 \\
Lintr & -0.651 & 0.03 & 0.006 & 0.84 \\
Divg & 0.002 & 0.19 & 0.007 & 0.41 \\
dir_in & -0.007 & 0.14 & -0.379 & 0.00 \\
Size & -0.008 & 0.49 & 0.400 & 0.00 \\
J-stat & 0.051 & 0.00 & 0.22 & \\
\hline Source: Aunyyyy & 0.25 & & & \\
\hline
\end{tabular}

Source: Author's computation (using EView 9.0), 2020. 
Table 7. The Linear Estimates using ROE

\begin{tabular}{l|ll|ll}
\hline \multirow{2}{*}{ Variable } & \multicolumn{2}{l}{ United States } & \multicolumn{2}{l}{ Oil and gas } \\
\cline { 2 - 5 } & \multicolumn{2}{l}{ Manufacturing } & Coefficient & Prob. \\
\cline { 2 - 5 } ROE(-1) & Coefficient & Prob. & 0.02 & 0.52 \\
LEV & 0.99 & 0.00 & -0.04 & 0.57 \\
TANG & 0.07 & 0.39 & 0.00 & 0.83 \\
NDTS & 0.33 & 0.00 & 0.00 & 0.62 \\
LINTR & -3.01 & 0.00 & -0.04 & 0.01 \\
DIVG & -0.01 & 0.00 & 0.01 & 0.08 \\
DIR_IN & 0.00 & 0.52 & 0.00 & 0.93 \\
SIZE & 0.00 & 0.94 & -0.12 & 0.00 \\
J-stat & 0.02 & 0.47 & 0.31 & \\
\hline
\end{tabular}

Source: Author's computation (using EView 9.0), 2020.

On the appropriate model to be used for the estimation of the firm capital structure-performance relationships, we estimate the equations using linear relationships for the functions. It should be noted that the GMM estimates does not incorporate the goodness of fit statistics of R-squared. Rather, the results presented contain the probability values of the J-statistic, which is a test for the appropriateness of the instruments employed in the GMM. For each of the estimates, the J-value has probability values that are greater than 0.1 , suggesting that the instruments used in the model are quite appropriate (under GMM application).

\subsection{Tests of Hypotheses}

The hypotheses tested in this study are based on the empirical analysis conducted in the previous sections. The focus is on the signs and significance if the estimated coefficients which provide inferential statistics for the hypotheses testing.

\subsubsection{Hypothesis One}

Capital Structure has no significant impact on performance of oil \& and gas and manufacturing industry performance in the United States.

In testing this hypothesis, the results of the overall-data based and the linear sector-based models are employed. From the results in the overall data, the coefficient of leverage was significant in the ROA model, but it failed the test in the ROE model. For the sector-based results, the coefficient of leverage passed the test for oil and gas sector for the ROA. Therefore, based on the outcome, the null hypothesis is rejected since certain leverage coefficients were significant. Hence, it is shown that capital structure has a significant positive impact on performance in both oil \& and gas and manufacturing industries.

\subsubsection{Hypothesis Two}

There is no linear relationship between capital structure and performance of oil \& and gas and manufacturing industry performance in the United States

The test of this hypothesis is based on the coefficients of leverage squared in the overall-data based models and the nonlinear estimates of the sector-based models. For the overall results, the coefficient of squared leverage was significant (at the one percent level) and negative in the ROA estimates, but failed the test at the 5 percent level for those of ROE. For the sector-based models, the coefficient of squared leverage passed the test at the one percent level for oil and gas sector for ROA estimate but failed the test at the 5 percent level for all the other estimates. This also suggests that the null hypothesis is rejected. This implies that there exists a linear relationship between capital structure and firm performance in both sectors.

\subsubsection{Hypothesis Three}

There is no difference between oil \& gas and manufacturing sectors in the United States in terms of effects of capital structure on performance

From all the results reported in the study (apart from the overall-data based estimates), it is empirically demonstrated that the results from the two industries were significantly different, thus, the null hypothesis is also rejected in this case. 


\section{Discussion of Findings}

In this study, impact of firms' capital structure on performance among oil \& gas and manufacturing firms in the United States was investigated. A comparative approach is adopted for the analysis by comparing these effects between firms in the two industries using data for companies in the industries. A non-linear model was specified for the relationship in order to capture the essential aspect of the differing impacts that rising debt accumulation in the firm could have on performance.

\subsection{Summary of Findings}

This study no doubt would be a major addition to the literature and research on capital structure, most especially in the oil \& gas and manufacturing sectors (cross-sectoral analysis). Therefore, the findings from this study in line with its objectives are as follows:

1. That capital structure generally has significant impact on firms' performance in both oil \& gas and manufacturing industries in the United States especially where ROA is used instead of ROE as measure of performance.

2. That there exists a significant non-linear relationship between capital structure and firm performance for the two industries. The effects are shown to be generally negative.

3. That overall, the impact of capital structure on firm performance significantly differs between the oil \& gas industry and manufacturing industry.

\subsection{Conclusion}

This paper has explored the effects of capital structure on firm performance in the oil \& gas and manufacturing sector in the United States. It also sought to identify certain pertinent differences existed between sectors in respect of the effects of capital structure on firms' performances.

Apparently, sectorial differences could account for the extent of debt use as well as the role of debt in efficiency either at the firm level or in the market. The effects of financial management in generating superior performance for a firm generally depend on the capital structure to a large extent. Indeed the possession of a source of sustained competitive advantage is not sufficient to obtain improved value; rather the financial policies of a firm should be in tandem with its sources of funding. The empirical analysis in the study revealed that sectoral differences actually accounts for leverage effects on performance both in extent and direction. The results are therefore consistent with the capital structure theory by Modigliani \& Miller (1963) which formed a basis for this study. It argues that firms can use debt to lower their cost of capital and maximize firm's value.

\subsection{Recommendations}

The findings made in the study give impetus for the following recommendations which are useful to both the market regulators, investors in the market and indeed the academia.

i. The high positive significance of the leverage coefficient in the oil \& gas sector shows that by lowering the debt in its capital structure composition, an oil \& gas firm can increase its overall performance. Importantly, the findings showed that the oil \& gas sector has a very strong debt schedule in their capital. It is therefore recommended that finance managers can maximize the wealth of shareholders by effectively utilizing debt on the ground of efficiency.

ii. Conversely, the manufacturing firms, an advisable means of increasing performance is to generally increase debt in the capital structure. There appears to be a generally wide margin within which more debt can be used to optimize performance for the firms in the sector. Manufacturing firms can therefore enhance their shareholders' wealth by increasing the debt component in their capital structure.

iii. About maximizing shareholders' wealth, a very important avenue for generating debt for the company should be the capital market.

iv. Finally, selection of debt as a source of capital finance should be done in line with the costs and benefits associated with the use of debt, otherwise it could be counterproductive and a pointer to bankruptcy.

\section{References}

Adesina, J. B., Nwidobie, B. M., \& Adesina, O. O. (2015). Capital structure and financial performance in Nigeria. International Journal of Business and Social Research, 5(2), 21.

Akeem, L. B., Terer, E. K., Kiyanjui, M. W., \& Kayode, A. M. (2014). Effects of capital structure on firm's performance: Empirical study of manufacturing companies in Nigeria. Journal of Finance and Investment Analysis, 3(4), 39-57. 
Amraoui, M., Jianmu, Y., \& Bouarara, K. (2018). Firm's capital structure determinants and financing choice by industry in Morocco. International Journal of Management Science and Business Administration, 4(3), 41-51. https://doi.org/10.18775/ijmsba.1849-5664-5419.2014.43.1005

Antoniou, A., Guney, Y., \& Paudyal, K. (2008). The determinants of capital structure: Capital market-oriented versus bank-oriented institutions. Journal of Financial and Quantitative Analysis, 43(01), 59-92. https://doi.org/10.1017/S0022109000002751

Bevan, A. A., \& Danbolt, J. (2004). Testing for inconsistencies in the estimation of UK capital structure determinants. Applied Financial Economics, 14(1), 55-66. https://doi.org/10.1080/0960310042000164220

Campello, M., \& Giambona, E. (2010). Asset tangibility and capital structure. Retrieved from http://www.ebs.edu/fileadmin/redakteur/ funkt.dept.../100323_Giambona.pdf

Chadha, S., \& Sharma, A. K. (2015). Capital structure and firm performance: Evidence from India. Vision-The Journal of Business Perspective, 19(4), 295-302. SAGE Publication. https://doi.org/10.1177/0972262915610852

Chou, S., \& Lee, C. (2010). Effects of capital structural firm performance and evidence from the non-financial industry of Taiwan 50 and Taiwan Mid-CAP 100 from 1987 - 2007. Department of financial operation, national Kaohsiung first university of science and technology, Staff working paper.

Dare, F. D., \& Sola, O. (2010). Capital structure and corporate performance in Nigeria petroleum industry: panel data analysis. Journal of Mathematics and Statistics, 6(2), 168-173. https://doi.org/10.3844/jmssp.2010.168.173

De Angelo, H., \& Masulis, R. (1980). Optimal capital structure under corporate and personal taxation. Journal of Financial Economics, 8, 3-29. https://doi.org/10.1016/0304-405X(80)90019-7

Demsetz, H., \& Villalonga, B. (2001), Ownership structure and corporate performance. Journal of Corporate Finance, 7 , 209-233. https://doi.org/10.1016/S0929-1199(01)00020-7

Dittman, A., \& Thakor, A. (2007). Why do firms issue equity? The Journal Finance, LX(1), 1-54. https://doi.org/10.1111/j.1540-6261.2007.01200.x

Dokua, I., Adjeib, E., Adjimahc, H., \& Akumad, J. (2017). Determinants of capital structure of listed oil marketing companies in Ghana. American Scientific Research Journal for Engineering, Technology, and Sciences (ASRJETS). ISSN (Print) 2313-4410, ISSN (Online) 2313-4402 (C) Global society of scientific research and researchers.

Emeh, \& Okoli. (2015). Determinants of capital structure in oil and gas sector in Nigeria. Merit Research Journal, 3(3), 035-045.

Endri, E., \& Fathony, M. (2020) Determinants of firm's value: Evidence from financial industry. Management Science Letters, 10(1), 111-120. https://doi.org/10.5267/j.msl.2019.8.011

Endri, E., Ridho, A. M., \& Harahap, I. M. (2019). Capital structure and profitability: evidence from mining companies in Indonesia. Business: Theory and Practice. ISSN: 1648-0627, E-ISSN: 1822-4202. https://doi.org/10.3846/btp.2019.19

Fama, E. F., \& French, K. R. (2002). Testing trade-off and pecking order prediction about dividends and debt. The Review of Financial Studies, 15(1), 1-33. https://doi.org/10.1093/rfs/15.1.1

Fan, J. P. H., Titman, S., \& Twite, G. (2011). An international comparison of capital structure and debt maturity choices. Journal of Financial and Quantitative Analysis, 5(16). ISSN: 2222-1697 (Paper), E-ISSN: 2222-2847 (Online).

Frank, M., \& Goyal, V. (2009). Testing the pecking order theory of capital structure. Journal of Financial Economics, 67, 217-248. https://doi.org/10.1016/S0304-405X(02)00252-0

Hassan, L., \& Samour, S. (2015). Capital structure and firm performance: Did the financial crisis matter? -A crossindustry study.

Im, Pesaran, \& Shin. (2003). Testing for unit roots in heterogeneous panels. Journal of Econometrics, 115, 53-74. https://doi.org/10.1016/S0304-4076(03)00092-7

Kakilli-Acaravci, S. (2015). The determinants of capital structure: evidence from the Turkish manufacturing sector. International Journal of Economics and Financial Issues, 5(1), 158-171. ISSN: 2146-4138. Retrieved from www.econjournals

Lemma, T., \& Negash, M. (2014). Determinants of the adjustment speed of capital structure: Evidence from developing economies. Journal of Applied Accounting Research, 15(1), 64-99. https://doi.org/10.1108/JAAR-03-2012-0023

Levin, A., Lin, C., \& Chu, J. (2002). Unit root tests in panel data: asymptotic and finite-sample properties. Journal of 
Econometrics, 108(1), 1-24, Elsevier. https://doi.org/10.1016/S0304-4076(01)00098-7

Miller, M. (1977). Debt or taxes. The Journal of Finance, 32(2), 261-275. https://doi.org/10.1111/j.15406261.1977.tb03267.x

Modigliani, F., \& Merton, H. M. (1958). The cost of capital, corporation finance and theory of investment. The American Economic Review, 48(3), 261-297.

Modigliani, F., \& Merton, H. M. (1963). Corporate income taxes and the cost of capital: a correction. American Economic Review, 53, 433-443.

Mokhtar, Yussof, \& Ahmad. (2014). Key elements of market orientation on Malaysian performance. International Journal of Business and Society, 15, 49-64.

Morellec, E. (2001). Asset liquidity, capital structure and secured debt. Journal of Financial Economics, 61, 173-206. https://doi.org/10.1016/S0304-405X(01)00059-9

Mursalim, M., \& Kusuma, H. (2017). Capital structure determinants and firms' performance: empirical evidence from Thailand, Indonesia and Malaysia. Polish Journal of Management Studies, 16, 1 https://doi.org/10.17512/pjms.2017.16.1.13

Ogebe, O. P., Ogebe, J. O., \& Alewi, K. (2013). The impact of capital structure on firm performance in Nigeria. https://doi.org/10.2139/ssrn.2266916

Oino, I., \& Ukaegbu, B. (2015). The impact of profitability on capital structure and speed of adjustment: An empirical examination of selected firms in Nigerian Stock Exchange. Research in International Business and Finance, 35, 111-121. https://doi.org/10.1016/j.ribaf.2015.03.004

Onaolapo, A. A., \& Kajola, S. O. (2010). Capital structure and firm performance: evidence from Nigeria. European Journal of Economics, Finance and Administrative Sciences, 25, 70-82.

Pouraghajan, A., \& Malekian, E. (2012). The relationship between capital structure and firm performance evaluation measures: Evidence from the Tehran stock exchange. International Journal of Business and Commerce, 1(9), 166181.

Rajan, R. G., \& Zingales, L. (1995). What do we know about capital structure? Some evidence from international data. Journal of Finance, American Finance Association, 50(5), 1421. https://doi.org/10.1111/j.15406261.1995.tb05184.x

Ramadan, Z. S., \& Ramadan, I. Z. (2015). Capital structure and firm's performance of Jordanian manufacturing sector. International Journal of Economics and Finance, 7(6), 45-67. https://doi.org/10.5539/ijef.v7n6p279

Richards, J., Devinney, T., Yip, G., \& Johnson, G. (2009). Measuring organizational performance: towards methodological best practice. Journal of Management, 35(3), 718. https://doi.org/10.1177/0149206308330560

Schwarz, G. E. (1978). Estimating the dimension of a model. Annals of Statistics, 6(2), 461. https://doi.org/10.1214/aos/1176344136

Shambor, A. Y. (2017). The determinants of capital structure: Empirical analysis of oil and gas firms. Asian Journal of Finance \& Accounting, 9(1). ISSN: 1946-052X. https://doi.org/10.5296/ajfa.v9i1.9359

Taghian, M., D'Souza, C., \& Polonsky, M. J. (2015). A stakeholder approach to corporate social responsibility, reputation and business performance. Deakin University research repository. (dro.deakin.edu.au). https://doi.org/10.1108/SRJ06-2012-0068

Tewara, M. (2016). A study on the determinants of capital structure and profitability. Journal of Financial Economics, 26(1), 3-27.

Titman, S., \& Wessels, R. (1988). The determinants of capital structure choice. Journal of Finance, 43(1), 1-19. https://doi.org/10.1111/j.1540-6261.1988.tb02585.x

\section{Copyrights}

Copyright for this article is retained by the author(s), with first publication rights granted to the journal.

This is an open-access article distributed under the terms and conditions of the Creative Commons Attribution license which permits unrestricted use, distribution, and reproduction in any medium, provided the original work is properly cited. 